\title{
PARTILHA DE BENS DO ESFORÇO COMUM NA UNIÃO ESTÁVEL
}

\section{Suelen Ribeiro Linhares Silva ${ }^{1}$ \\ Ana Maria Viola de Sousa ${ }^{2}$ \\ Maurício Martins Alves ${ }^{3}$}

Resumo: O presente artigo, ao tratar do esforço comum na união estável submetida ao regime de separação obrigatória de bens, visa analisar a partilha de bens e os efeitos jurídicos resultantes de sua dissolução a partir da análise da Constituição Federal de 1988 e de legislação infraconstitucional, bem como de doutrina e jurisprudência do STJ (Superior Tribunal de Justiça) que defende que a partilha do patrimônio dos casais que vivem em união estável submetidos ao regime de separação obrigatória de bens não será de forma automática.

Palavras-chave: Partilha de Bens; União estável; Esforço Comum.

\footnotetext{
1 Direito/Univap, Brasil. E-mail: suelen_linhares@hotmail.com.

2 Direito/Univap, Brasil. E-mail: anaviola@aasp.org.br.

3 Direito/Univap, Brasil. E-mail: mmalves@univap.br.
} 